\title{
Use of Lichen and Moss in Assessment of Forest Contamination with Heavy Metals in Praded and Glacensis Euroregions (Poland and Czech Republic)
}

\author{
Andrzej Kłos • Malgorzata Rajfur • Ivo Šrámek • \\ Maria Waclawek
}

Received: 25 February 2011 / Accepted: 2 May 2011 /Published online: 27 May 2011

(C) The Author(s) 2011. This article is published with open access at Springerlink.com

\begin{abstract}
The concentrations of selected metals - $\mathrm{Cr}$, $\mathrm{Ni}, \mathrm{Cu}, \mathrm{Zn}, \mathrm{Cd}$, and $\mathrm{Pb}$ - were determined in the samples of Hypogymnia physodes lichen and Pleurozium schreberi moss collected in Polish and Czech Euroregions Praded and Glacensis. More specifically, the samples were collected in Bory Stobrawskie, Bory Niemodlińskie, and Kotlina Kłodzka (Poland) and in Jeseniki (Czech Republic). The concentration of metals in the samples was measured using the atomic absorption spectrometry (flame AAS technique and electrothermal atomization AAS technique). The results were used to calculate the comparison factor (CF) that quantifies the difference in concentration of a given bioavailable analyte $\times$ accumulated in lichens and mosses: $\mathrm{CF}=2\left(c_{\mathrm{x}, \text { lichen }}-c_{\mathrm{x}, \text { moss }}\right)\left(c_{\mathrm{x} \text {,lichen }}+c_{\mathrm{x}}\right.$, moss $)^{-1}$. The values of CF greater than 0.62 indicate the most probable location of heavy metals deposited in the considered area. In this work, the method was used to show a significant contribution of urban emissions to the deposition of heavy metals in the
\end{abstract}

A. Kłos $(\bowtie) \cdot$ M. Rajfur $\cdot$ M. Wacławek

Chair of Biotechnology and Molecular Biology, Opole

University,

4 kard. B. Kominka Str,

45-032 Opole, Poland

e-mail: aklos@uni.opole.pl

I. Šrámek

Health Institute in Hradec Králové (ZÚHK),

Habrmanova 154,

501-01 Hradec Králové, Czech Republic

e-mail: ivo.sramek@zu.cz area of Bory Stobrawskie and in the vicinity of Kłodzko City.

Keywords Heavy metals · Biomonitoring · Lichen · Moss $\cdot$ Comparison factor

\section{Introduction}

The living organisms that react to changes in the chemical composition of the environment are more and more often employed in the assessment of the environmental pollution (Wolterbeek 2003; Markert et al. 2003; Smodiš et al. 2004; Markert 2007). Good examples are the use of lichens in the Integrated Monitoring of Natural Environment System and the use of biological material in the quality evaluation of natural waters (Directive 2000/60/EC).

Lichens and mosses dominate among organisms used for evaluation of pollution by atmospheric aerosols (Fraenzle and Markert 2007; Markert et al. 2008). Most often, the biomonitoring is done by analyzing the chemical composition of lichens and mosses collected from their natural environment (e.g., Loppi and Bonini 2000; Szarek-Łukaszewska et al. 2002). The accumulation of micro- and macroelements in biomonitors exposed to polluted atmosphere is measured with instrumental analytic methods (Frontasyeva et al. 1995; Markert 1996).

In urban and industrial areas, the exposition techniques often used are those that utilize living 
organisms transferred from the relatively pristine areas (e.g., Culicov and Yurukova 2006; Kosior et al. 2010). The time-controlled exposition of these organisms provides more information on the deposition of pollutants in such areas.

The results of biomonitoring are usually interpreted with the comparative analysis (Daillant et al. 2003; Bergamaschi et al. 2004) and other statistical methods: factor analysis (Jasan et al. 2004), regression analysis (Riga-Karandinos and Karandinos 1998), principal component analysis-PCA (Sorbo et al. 2008), cluster analysis (Fuga et al. 2008), and time series - TS (Reis et al. 2003). A good example is the application of data clustering and PCA to the interpretation of results on the concentration distribution of elements accumulated in mosses exposed in the urban area of the Gdańsk City in Poland (Szczepaniak et al. 2007). The work evaluated the usability of dry and living moss Sphagnum palustre in the biomonitoring studies.

In order to assess the sources of analytes accumulated in mosses or lichens, the results are analyzed using the enrichment factor (EF), which compares the relative concentration of an analyte accumulated in lichens or mosses to that in soil. The reference elementsscandium and aluminum - rarely appear in atmospheric aerosols from anthropogenic sources (Bargagli et al. 1995; Bergamaschi et al. 2005). The sum of concentrations of the rare-earth elements was also suggested as a suitable reference quantity (Chiarenzelli et al. 2001). By definition, the enrichment factor close to unity $(\mathrm{EF}=1)$ indicates that a given element originates from soil (Chiarenzelli et al. 2001). However, some authors argue that the values of $\mathrm{EF}<10$ correspond to the measurement background; hence, the values do not show whether the source of analytes accumulated in lichens and mosses was the soil or some other remote source of emission (Chiarenzelli et al. 2001; Freitas et al. 2007). Disagreement between the real source of the analytes and the remote sources indicated by the high values of EF can result from the uncertainty of the measuring method, from inhomogeneity of the chemical composition of the samples used, and from the very definition of EF. Enrichment factors are determined from the concentrations of analytes in the soil, lichens, and mosses; but mosses and lichens accumulate only bioaccessible forms of the pollutants. Moreover, bioaccumulation is affected by the chemical characteristics of compounds which contain the examined analytes (mainly the ability of compounds to form ionic forms), as well as by the affinity of the ionic forms of compounds to the sorption structures of mosses and lichens.

The idea of using lichens and mosses as bioindicators and biomonitors is still a matter of discussion between scientists. The authors argue on the sorption preferences of lichens and mosses, both living under natural conditions and then transferred for exposition from the ecologically pristine regions to the polluted areas (Kashulina et al. 1998). The research showed that under natural conditions, mosses preferred to accumulate $\mathrm{Al}, \mathrm{Ca}, \mathrm{Cr}$, and $\mathrm{Ni}$ (Gałuszka 2005) or $\mathrm{Al}, \mathrm{Cr}, \mathrm{Fe}$, $\mathrm{Mn}, \mathrm{Ni}$, and Ti (Bargagli et al. 2002); while lichens preferred $\mathrm{Cu}, \mathrm{Hg}, \mathrm{Na}$, Ti, and $\mathrm{Zn}$ (Gałuszka 2005) or $\mathrm{Cd}, \mathrm{Cu}, \mathrm{Hg}, \mathrm{Pb}, \mathrm{V}$, and $\mathrm{Zn}$ (Bargagli et al. 2002). Metals such as $\mathrm{Cd}, \mathrm{Fe}$, and $\mathrm{Pb}$ were accumulated comparably (Gałuszka 2005). On highly contaminated soils, mosses usually accumulated more analytes than lichens (Reimann, et al. 1999). The opposite tendency was observed in regions with volcanic exhalations that enriched the atmospheric aerosol (Loppi et al. 1999).

This work presents a statistical assessment of pollution in the considered regions and introduces a new evaluation method which is based on the comparison of analyte contents in epiphytic lichens and epigeal mosses living close to each other. The epigeal mosses accumulate comparable or larger amounts of elements from the soil, including the previously deposited anthropogenic elements. On the contrary, the epiphytic lichens accumulate comparable or larger amounts of analytes that had not been locally translocated to the atmospheric aerosol from the soil (Kłos et al. 2010). In epigeal mosses, the sorption of microelements transported from remote sources is limited by the easily available macroelements from the soil, which are less available for the epiphytic lichens. The influence of macroelements on sorption of microelements was discussed elsewhere (Hyvärinen and Crittenden 1996; Hauck et al. 2002; Kłos et al. 2005, 2007). The presented research was part of the Operational Programme for Transboundary Cooperation between Czech Republic and Poland, entitled "Biomonitoring research in Polish-Czech transboundary region."

\section{Materials and Methods}

The research was carried out in the forested areas of the Praded and Glacensis Euroregions-Bory Stobrawskie 
(BS), Bory Niemodlińskie (BN), and Kotlina Kłodzka $(\mathrm{KK})$ in Poland and Jeseniki (J) in the Czech Republic. The selected areas had similar tree cover (pine and spruce forests), but differed in the geological structure of soil. In Bory Niemodlińskie and Bory Stobrawskie, the sand soil was covered with humus layer at least $3 \mathrm{~cm}$ thick. The geologically inhomogeneous soil in Kotlina Kłodzka and Jeseniki was typical for the Sudety Mountain range. Samples of the epiphytic lichen Hypogymnia physodes and the epigeal moss Pleurozium schreberi were collected from April to September 2010. Figure 1 shows the localization of sampling sites.

\subsection{Collection and Preparation of Samples}

The samples of lichen and moss were collected at the sites shown in Fig. 1, from six points at each site. Lichen was collected from horizontally growing branches of spruce and larch trees, at 1.5-2 $\mathrm{m}$ above the ground level. Lichen samples from six points at a site were mixed together. The moss samples were mixed together accordingly. The total mass of samples collected at each site was $20 \mathrm{~g}$ of lichen and $20 \mathrm{~g}$ of moss. The samples were cleaned from mechanical impurities and dried at temperatures not higher than $303 \mathrm{~K}$. Dried samples were homogenized in agate mortars and subjected to AAS measurements.

\subsection{Analysis}

The prepared samples were analyzed independently in the accredited laboratory of the Health Institute in Hradec Králové (Zdravotního ústavu v Hradci Králové-ZÚHK) and at the Chair of Biotechnology

Fig. 1 Map with localization of sampling sites and Molecular Biology, University of Opole (UO). Metals were determined with the flame AAS technique (F-AAS). Concentrations of $\mathrm{Cr}$ smaller than the detection limit of F-AAS were determined with the electrothermal atomization AAS technique (ETAAAS). Table 1 shows the details of analytical procedures, reagents, and equipment used.

\subsection{Quality Assessment/Quality Control}

For the proper quality assurance and control in the analysis of metals in lichen and moss samples, the method quantification limit values were determined both in the ZÚHK ( $\mu \mathrm{g} \mathrm{g}^{-1}: 0.13(\mathrm{Cd}), 0.5(\mathrm{Cr}, \mathrm{Cu}, \mathrm{Ni}$, $\mathrm{Zn}, \mathrm{Pb})$, and $0.025(\mathrm{Cr}$, ETA-AAS)) and in the UO $\left(\mu \mathrm{g} \mathrm{g}^{-1}: 0.5(\mathrm{Cu}, \mathrm{Zn}, \mathrm{Cd}), 0.7(\mathrm{Ni})\right.$, and $\left.1.3(\mathrm{~Pb})\right)$ laboratories.

The reference material BCR-482 lichen from the Institute for Reference Materials and Measurements, Belgium was also analyzed. The results of analysis are compared to the certified values in Table 2.

Maximal deviations between the mean values of metal concentrations determined in the collected samples in ZÚHK and in UO were (respectively for lichen and moss): $\mathrm{Ni}(9.7 \%$ and $7.5 \%), \mathrm{Cu}(8.7 \%$ and $3.9 \%), \mathrm{Zn}(5.8 \%$ and $9.3 \%), \mathrm{Cd}(9.6 \%$ and $10.3 \%)$, and $\mathrm{Pb}(7.1 \%$ and $10.5 \%)$. Chromium was determined only in the ZÚHK laboratory.

\subsection{Statistical Analysis and Data Interpretation}

All statistical computations were done using the $\mathrm{R}$ language ( $R$ Development Core Team 2009). $R$ is a free software environment for statistical computation

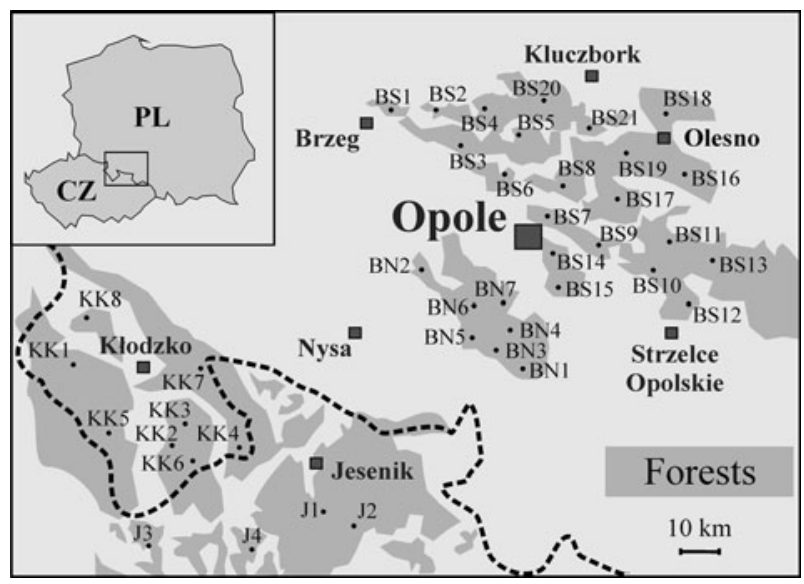


Table 1 Details of analytical procedures, reagents, and equipment

\begin{tabular}{lll}
\hline Description & ZÚHK & UO \\
\hline Mass of mineralized samples & $1.0 \mathrm{~g}$ & $1.0 \mathrm{~g}$ \\
Type of digestion & Mineralization by dry MLS-1200 MEGA & Microwave digestion MARS-X \\
Acid used for digestion & $\mathrm{HNO}_{3}(65 \%)$ and $\mathrm{H}_{2} \mathrm{O}_{2}$ & Aqua regia \\
Type of AAS & $\mathrm{SOLAAR} \mathrm{M5,} \mathrm{AVANTA} \mathrm{SUMA,} \mathrm{from} \mathrm{UNICAM}_{2}$ & SOLAAR 969 from UNICAM \\
Standards for calibration & ANALYTIKA Ltd. (CZ) & ANALYTIKA Ltd. (CZ) \\
Reagents & MERCK & Scharlau \\
\hline
\end{tabular}

and graphics. The capabilities of $\mathrm{R}$ can be extended through packages for specialized statistical techniques, graphical devices, programming interfaces, and import/export function to many external data formats.

The results of research were analyzed using the comparison factor (CF) defined as a ratio of a difference between the analyte concentrations in lichen $\left(c_{\mathrm{i}, \text { lichen }}\right)$ and in moss $\left(c_{\mathrm{i} \text {,moss }}\right)$, to the average of these concentrations: $\mathrm{CF}=2 \cdot\left(c_{\mathrm{i}, \text { lichen }}-c_{\mathrm{i} \text {,moss }}\right) \cdot\left(c_{\mathrm{i} \text {,lichen }}+c_{\mathrm{i}, \mathrm{moss}}\right)^{-1}$.

Kłos et al. (2010) showed that $\mathrm{CF}>0.62$ determined the deposition zones of heavy metals which had been introduced to the atmosphere by primary emission and not by the secondary enrichment of atmospheric aerosol with local contaminants from the soil. Obviously, this interpretation applies to the bioavailable forms of considered analytes. The limiting value of CF was determined by the analysis of a data set containing the concentrations of heavy metals accumulated in samples of epiphytic lichens and epigeal mosses from our own measurements and from 257 published measurements in various regions of Europe. In the range $-0.62<\mathrm{CF}<0.62$, which contained $67 \%$ of all results, a statistically significant relation $c_{\mathrm{i} \text {,moss }}=c_{\mathrm{i} \text {,lichen }}$ was valid (Kłos et al. 2010).

\section{Results and Discussion}

Table 3 shows the mean concentrations of analytes accumulated in lichen and moss samples collected in $\mathrm{BS}, \mathrm{BN}, \mathrm{KK}$, and $\mathrm{J}$. The table includes the uncertainties of the analytical method, $\pm \mathrm{SD}_{\mathrm{AM}}(\%)$, determined from the results for samples collected at sites BS1, BN1, KK1, and J1 (Fig. 1). For this purpose, five samples of lichen and five samples of moss were collected at each site. Each sample was independently cleaned, homogenized, mineralized, and analyzed. The determined values of $\pm \mathrm{SD}_{\mathrm{AM}}$ are comparable with the corresponding values obtained from a study carried out in 2006 in BS (Kłos 2009).

The distribution of concentrations of each metal accumulated in lichen and moss samples collected in the forested areas BS, BN, KK, and J was described by specifying the maximum and the minimum values,

Table 2 Comparison of measured and certified data for BCR 482 lichen $\left(\mu \mathrm{g} \mathrm{g}^{-1}\right)$

\begin{tabular}{|c|c|c|c|c|c|c|}
\hline \multirow[t]{2}{*}{ Element } & \multirow{2}{*}{$\begin{array}{l}\text { BCR-482 lichen } \\
\text { Certified value } \\
\left(\mu \mathrm{g} \mathrm{g}^{-1}\right)\end{array}$} & \multicolumn{4}{|l|}{ AAS (UO; \%) } & \multirow[t]{2}{*}{ AAS (ZÚHK) ND ${ }^{\mathrm{b}}(\%)$} \\
\hline & & \pm Uncertainty & Mean & $\pm \mathrm{SD}$ & $D^{\mathrm{a}}$ & \\
\hline $\mathrm{Cr}$ & 4.12 & 0.15 & n.d. & n.d. & n.d. & 20 \\
\hline $\mathrm{Ni}$ & 2.47 & 0.07 & 2.16 & 0.32 & -13 & 20 \\
\hline $\mathrm{Cu}$ & 7.03 & 0.19 & 6.54 & 0.18 & -7.0 & 10 \\
\hline $\mathrm{Zn}$ & 100.6 & 2.2 & 93.9 & 2.5 & -6.7 & 10 \\
\hline $\mathrm{Cd}$ & 0.56 & 0.02 & 0.50 & 0.04 & -6.3 & 20 \\
\hline $\mathrm{Pb}$ & 40.9 & 1.4 & 37.6 & 0.9 & -7.6 & 20 \\
\hline
\end{tabular}

\footnotetext{
${ }^{a}$ Deviation, the instrumentally measured/certified value expressed (in \%) between the results obtained by AAS and the certified value ${ }^{\mathrm{b}}$ Uncertainty of the analytical method (in \%) determined for various organic reference materials, as specified in the laboratory accreditation
} 
Table 3 Heavy metal content in lichens (L) and mosses $\left(\mathrm{M} ; \mu \mathrm{g} \mathrm{g}^{-1}\right)$

\begin{tabular}{|c|c|c|c|c|c|c|c|c|c|c|c|c|}
\hline \multirow[t]{2}{*}{ Sample no. } & \multicolumn{2}{|l|}{$\mathrm{Cr}$} & \multicolumn{2}{|l|}{$\mathrm{Ni}$} & \multicolumn{2}{|l|}{$\mathrm{Cu}$} & \multicolumn{2}{|l|}{$\mathrm{Zn}$} & \multicolumn{2}{|l|}{$\mathrm{Cd}$} & \multicolumn{2}{|l|}{$\mathrm{Pb}$} \\
\hline & $\mathrm{L}$ & M & $\mathrm{L}$ & M & $\mathrm{L}$ & M & $\mathrm{L}$ & M & $\mathrm{L}$ & M & $\mathrm{L}$ & M \\
\hline $\mathrm{BS} 1$ & .00 & 0.600 & 3.00 & 1.91 & 6.25 & 5.03 & 61.5 & 23.0 & 0.41 & 0.174 & 13.5 & 2.42 \\
\hline BS2 & 0.88 & 0.412 & 1.14 & 14.0 & 3.49 & 3.23 & 58.7 & 26.4 & 0.42 & 0.183 & 9.55 & 2.23 \\
\hline BS3 & 0.65 & 0.484 & 1.08 & 0.645 & 3.25 & 4.22 & 65.5 & 36.9 & 0.44 & 0.285 & 9.35 & 2.50 \\
\hline BS4 & 0.80 & 0.390 & 1.92 & 0.580 & 5.72 & 7.09 & 63.6 & 48.0 & 0.55 & 0.377 & 9.81 & 5.34 \\
\hline BS5 & 0.38 & 0.445 & 1.18 & 0.715 & 4.55 & 9.11 & 64.0 & 41.3 & 0.98 & 0.402 & 6.14 & 2.67 \\
\hline BS6 & 1.30 & 0.500 & 0.78 & 0.722 & 5.23 & 5.02 & 75.0 & 40.3 & 0.64 & 0.882 & 13.7 & 3.58 \\
\hline BS7 & 1.42 & 1.20 & 0.78 & 0.572 & 4.19 & 5.14 & 71.3 & 50.3 & 0.65 & & 13.0 & 5.41 \\
\hline BS8 & 1.10 & 0.513 & 1.52 & 0.279 & 3.45 & 2.98 & 104 & 31.8 & 0.63 & 0.433 & 13.1 & 3.74 \\
\hline BS9 & 1.66 & 0.910 & 2.23 & 1.72 & 4.64 & 7.36 & 134 & 43.5 & 1.03 & 0.485 & 14.1 & 4.02 \\
\hline BS10 & 1.18 & 0.875 & 0.94 & 0.965 & 4.33 & 5.12 & 97.0 & 54.8 & 1.36 & 0.822 & 17.2 & 6.20 \\
\hline BS11 & 0.50 & 0.380 & 0.85 & 0.538 & 4.48 & 5.15 & 68.9 & 115 & 1.04 & 0.485 & 11.8 & 3.21 \\
\hline BS12 & 1.03 & 1.25 & 2.21 & 0.980 & 4.37 & 4.55 & 152 & 34.4 & 2.23 & 0.428 & 25.2 & 8.88 \\
\hline BS13 & 1.65 & 1.03 & 1.08 & 1.06 & 3.28 & 3.78 & 114 & 41.9 & 1.46 & 0.843 & 22.0 & 8.07 \\
\hline BS14 & 1.30 & 1.23 & 0.94 & 0.959 & 5.59 & 8.42 & 104 & 58.5 & 1.16 & 0. & 28.6 & 7.51 \\
\hline BS15 & 1.58 & 0.525 & 1.09 & 1 & 6.05 & 10.4 & 133 & 74.9 & 1.50 & 0. & 34.7 & 11.9 \\
\hline BS16 & 53 & 1.00 & 1.47 & 1 & 4.59 & 10.1 & 129 & 63.7 & 1.25 & 0. & 20.3 & 6.01 \\
\hline BS17 & 1.28 & 1.30 & 1.20 & 1.00 & 4.56 & 6.66 & 120 & 113 & 0.85 & 0.248 & 17.4 & 7.17 \\
\hline BS18 & 1.80 & 1.00 & 1.59 & 1 & 8.61 & 7.21 & 110 & 54.2 & 0.87 & 0.373 & 17.3 & 1.38 \\
\hline $\mathrm{BS}$ & 0 & 0.8 & 1.29 & 0 & 4.36 & 4 & 125 & 49.3 & 7 & s & 1 & 2.28 \\
\hline BS20 & 1.30 & 1.55 & 0.95 & 1.79 & 4.07 & 4.01 & 63.8 & 26.6 & 0.39 & 75 & 9.85 & 1.83 \\
\hline BS21 & 2.28 & 0.950 & 1.23 & 0.627 & 4.52 & 6.67 & 65.7 & 18.4 & 0.71 & 0.295 & 16.0 & 4.09 \\
\hline BN1 & 1.25 & 1.25 & 2.01 & 1 & 5.10 & 5 & 60.0 & 49.5 & 3.00 & 3. & 20.1 & 17.2 \\
\hline $\mathrm{BN} 2$ & 1.20 & 2.60 & 1.53 & 2.98 & 6.05 & 14.2 & 76.5 & 81.5 & 1.90 & 1.25 & 15.3 & 35.7 \\
\hline $\mathrm{BN} 3$ & 1.25 & 1.50 & 1.52 & 1.95 & 4.40 & 9.35 & 84.5 & 89.5 & 1.35 & 5.50 & 15.2 & 23.5 \\
\hline BN4 & 1.00 & 0.95 & 1.43 & & 6.85 & 7.35 & 44.5 & 87.0 & 1.95 & 150 & 142 & 18.0 \\
\hline BN5 & 1.65 & 3.70 & 2.31 & 1.39 & 12.6 & 9.90 & 85.5 & 82.0 & 1.25 & 1. & 23.1 & 16.7 \\
\hline BN6 & 2.45 & 4.30 & 2.34 & 2.49 & 7.30 & 13.7 & 75.0 & 94.0 & 1.75 & 1.65 & 23.4 & 29.9 \\
\hline BN7 & 1.90 & 2.35 & 2.36 & 1.60 & 7.35 & 7.70 & 64.5 & 106 & 3.55 & 2.15 & 23.6 & 19.2 \\
\hline KK1 & 1.58 & 0.800 & 1.30 & 0.880 & 4.34 & 5.76 & 141 & 36.2 & 1.26 & 0.160 & 13.6 & 5.81 \\
\hline KK2 & 2.50 & 4.69 & 1.83 & 4.24 & 5.80 & 5.95 & 80.7 & 39.7 & 0.72 & 0.665 & 12.5 & 2.55 \\
\hline KK3 & 2.89 & 3.81 & 2.13 & 2.05 & 6.85 & 7.45 & 109 & 47.8 & 1.07 & & 10.8 & 2.89 \\
\hline KK4 & 2.27 & 3.33 & 1.35 & 1.81 & 3.70 & 7.05 & 47.5 & 48.5 & 1.64 & 0.795 & 11.6 & 7.61 \\
\hline KK5 & 1.87 & 3.23 & 1.33 & 1.30 & 5.15 & 3.65 & 55.9 & 32.7 & 0.81 & 0.595 & 6.27 & 4.31 \\
\hline KK6 & 2.64 & 3.43 & 2.03 & 1.63 & 7.05 & 4.65 & 79.4 & 33.0 & 1.52 & 0.258 & 14.4 & 3.68 \\
\hline KK7 & 2.26 & 9.47 & 3.91 & 4.20 & 16.9 & 11.9 & 100 & 50.7 & 1.68 & 0.920 & 18.0 & 4.84 \\
\hline KK8 & 1.76 & 4.45 & 1.54 & 1.42 & 7.28 & 13.0 & 84.8 & 34.1 & 0.66 & 1.03 & 10.9 & 4.33 \\
\hline $\mathrm{J} 1$ & 3.50 & 5.25 & 2.89 & 2.53 & 6.35 & 12.2 & 125 & 70.0 & 1.35 & 1.45 & 28.9 & 25.3 \\
\hline $\mathrm{J} 2$ & 3.45 & 3.30 & 2.38 & 1.56 & 7.40 & 10.1 & 102 & 55.5 & 1.05 & 1.10 & 23.8 & 15.6 \\
\hline $\mathrm{J} 3$ & 3.10 & 3.00 & 0.740 & 1.19 & 6.35 & 12.6 & 99.0 & 170.5 & 1.20 & 1.40 & 7.40 & 11.9 \\
\hline $\mathrm{J} 4$ & 3.10 & 3.45 & 1.26 & 1.69 & 7.30 & 5.50 & 71.0 & 51.0 & 1.40 & 0.950 & 12.6 & 16.9 \\
\hline$\pm \mathrm{SD}_{\mathrm{AM}}(\%)$ & 20 & 20 & 18 & 16 & 10 & 12 & 7.7 & 10 & 9.9 & 12 & 8.4 & 13 \\
\hline
\end{tabular}

the upper and the lower quartiles, the median value, and the outlying points (McGill et al. 1978). Graph- ical representation of this description is shown in Figs. 2 and 3. 
Fig. 2 Statistical parameters of distributions of $\mathrm{Cr}$, $\mathrm{Ni}$, and $\mathrm{Cu}$ concentrations in lichen and moss samples collected in BS, $\mathrm{BN}, \mathrm{KK}$, and $\mathrm{J}$

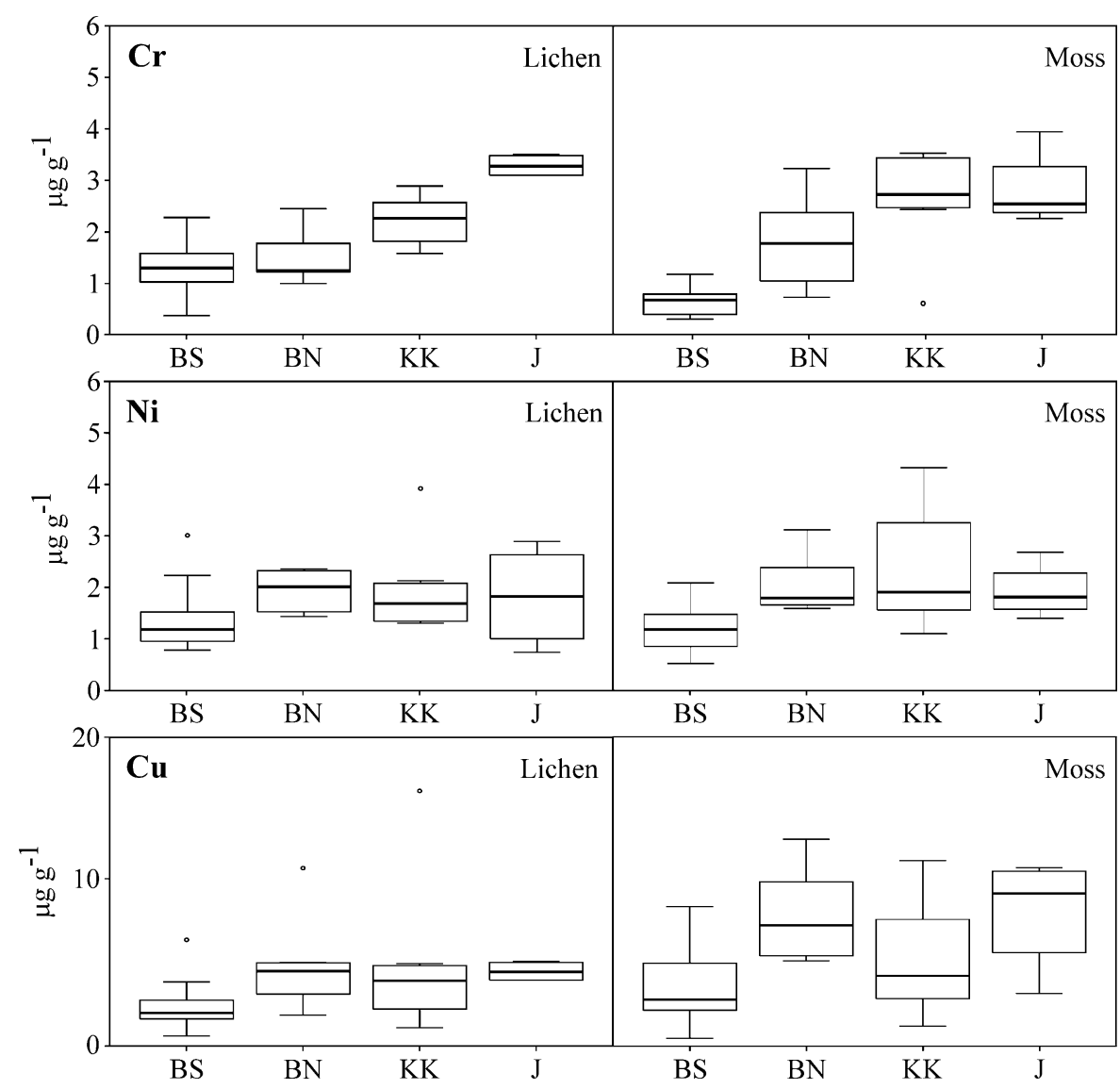

The statistical description presented in Figs. 2 and 3 indicates differences in concentration of analytes in the samples of lichen and moss collected in BS, BN, $\mathrm{KK}$, and $\mathrm{J}$. The concentration of $\mathrm{Cu}, \mathrm{Zn}, \mathrm{Cd}$, and $\mathrm{Pb}$ was higher in mosses from $\mathrm{BN}$ and $\mathrm{J}$. Lichen from these areas contained higher concentration of $\mathrm{Cu}, \mathrm{Cd}$, and $\mathrm{Pb}$. Plots in Figs. 2 and 3 indicate significant inhomogeneity of concentrations of some analytes in lichen and in moss samples from some areas, e.g., the inhomogeneity of $\mathrm{Zn}$ and $\mathrm{Pb}$ concentrations in lichen samples from BS.

When assessing the pollution of a specified area by determination of analytes in lichen and moss samples, it is important to compare the obtained results to the results from similar monitoring in the other regions of Europe. The available data for lichen are incomplete, since the systematic research has been done only in Portugal. On the other hand, many countries carry out systematic determination of heavy metals in mosses every 5 years, starting from 1990. In 2005, a more or less intensive research was done in 28 European countries (Harmens et al. 2010). The obtained results, presented as minimum/mean/maximum values in $\mu \mathrm{g} \mathrm{g}^{-1}$, were: $\mathrm{Cr}(0.28 / 1.81 / 12.7)$, Ni $(0.24 / 1.74 /$ 50.6), $\mathrm{Cu}(0.69 / 6.25 / 38.8), \mathrm{Zn}(5.2 / 33.0 / 77.4) \mathrm{Cd}$ $(0.031 / 0.18 / 0.57)$, and $\mathrm{Pb}(0.67 / 4.19 / 23.6)$. For the Opole region (Fig. 1), which was included in the research, the mean values in $\mu \mathrm{g} \mathrm{g}^{-1}$ were: $\mathrm{Cr}$ (2.74), $\mathrm{Ni}$ (2.56), and $\mathrm{Zn}$ (64.3; $\mathrm{Cu}, \mathrm{Cd}$, and $\mathrm{Pb}$ were not determined). These values compare well to the results contained in Table 3 and presented in Figs. 2 and 3. The contents of $\mathrm{Cd}$ determined in the present work were much higher than the maximum values observed in the aforementioned 2005 project. This is in good agreement with results from the joint project of the Vysehrad Group countries (Hungary, Czech Republic, Poland, and Slovakia) which showed high accumulation of $\mathrm{Cd}$ in mosses $\left(0.55-7.12 \mathrm{mg} \mathrm{g}^{-1}\right)$ in the Upper Silesia, an industrial region in Poland located close to the area monitored in the present work (Suchara et al. 2007). High accumulation of Cd was also observed in the Czech Republic, and in the Holy Cross Mountains 
Fig. 3 Statistical parameters of distributions of $\mathrm{Zn}$, $\mathrm{Cd}$, and $\mathrm{Pb}$ concentrations in lichen and moss samples collected in BS, $\mathrm{BN}, \mathrm{KK}$, and $\mathrm{J}$
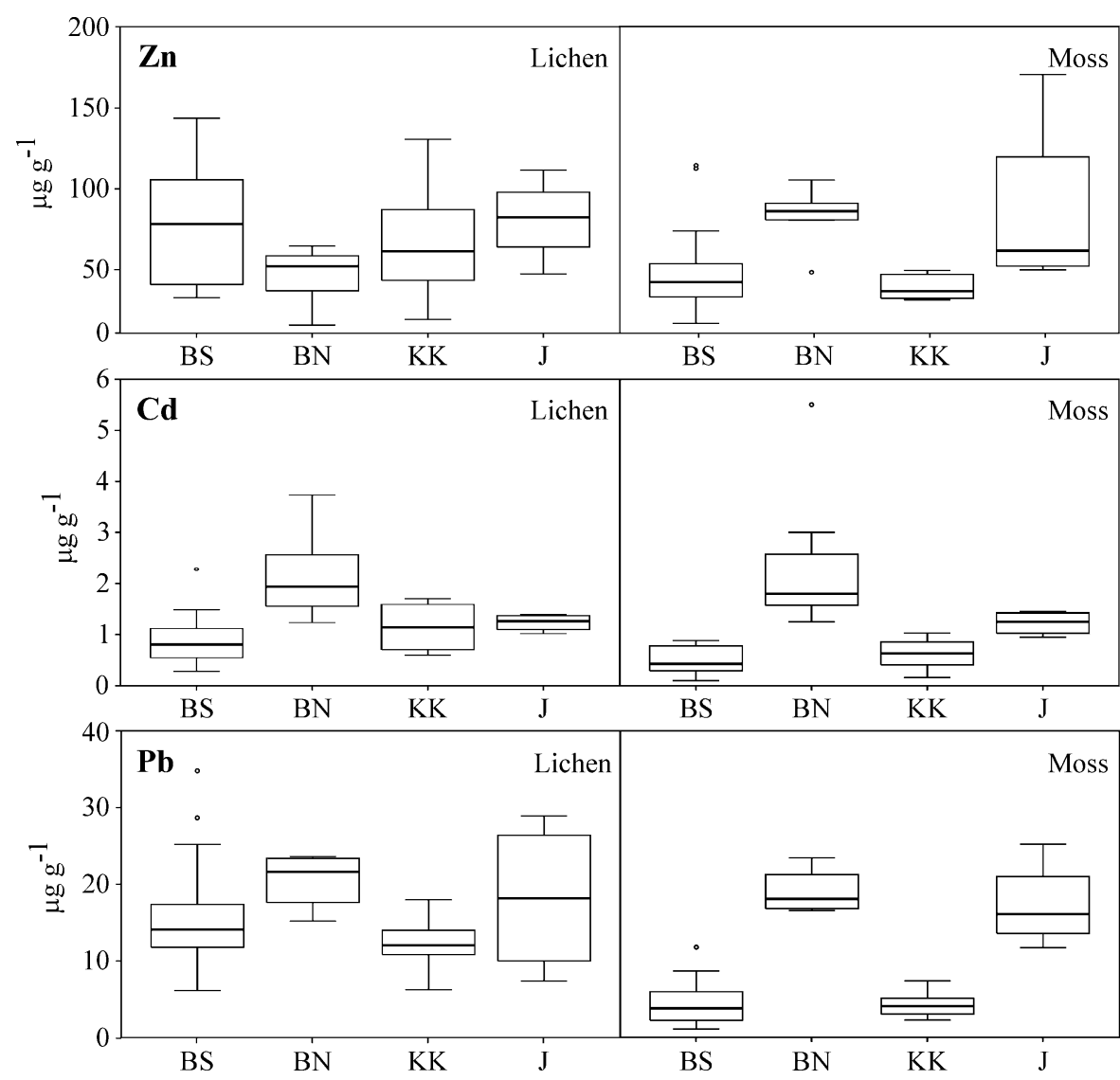

in South-Central Poland, where $0.8-1.1 \mathrm{mg} \mathrm{g}^{-1}$ of $\mathrm{Cd}$ was determined in moss samples (Gałuszka 2005).

The comparison of concentrations of heavy metals accumulated in lichen or in moss allows the general assessment of pollution in a given region, while the kind and the quantitative proportion of these metals indicate their sources (Lucaciu et al. 2004). The evaluation of current deposition of pollutants originating from the remote sources of emission requires additional analysis, such as the TS analysis mentioned in Section 1. The inflowing character of pollutants can also be judged from the highly uncertain enrichment factor.

The deposition of bioavailable forms of heavy metals injected to the atmosphere with primary emissions was evaluated using the determined values of comparison factor, CF. The maps in Fig. 4 show the areas for which $\mathrm{CF}>0.62$.

Plots in Fig. 4 indicate significant deposition of all considered metals except $\mathrm{Cu}$ in the area north-east to the city of Opole (the BS region), and around the city of Kłodzko (the KK region). This distribution resulted from the local meteorological conditions.

North and south winds, which dominate in the vicinity of the Opole City, transport urban and industrial pollutants from the city and from the local-district towns Brzeg and Strzelce Opolskie directly to the BS area. In Kłodzko, the south winds slightly prevail, but windless weather occurs oftene.g., for about $26.1 \%$ of time in 1971-2000 (Ecophysiographic Development 2005). Therefore, the deposition of metals in the KK area results rather from the local emissions.

The main sources of $\mathrm{Zn}$ emission in the BS area are cement works located directly in the Opole City, in the Górażdże village located about $20 \mathrm{~km}$ south-east from Opole, and in Strzelce Opolskie located $30 \mathrm{~km}$ south-east from Opole. The recorded average emission of $\mathrm{Zn}$ was $0.293 \mathrm{~kg}$ per $1 \mathrm{Gg}$ of manufactured cement (Olendrzyński et al. 2003). The cement works incinerate their wastes on-site, which can increase the emission of considered 
analytes. Other serious emission sources include urban emissions resulting mostly from combustion of fossil fuels, vehicle emissions, and emissions from numerous minor industrial facilities located in the area. For instance, in the Brzeg town, there is a tannery - a potential emitter of $\mathrm{Cr}$.

The concentration of industrial facilities in the area of Kotlina Kłodzka is low, so the main sources of $\mathrm{Zn}, \mathrm{Cd}$, and $\mathrm{Pb}$ emission are household facilities and local electric power stations fired with fossil fuels.

The determined CF values do not indicate any current deposition of metals in the $\mathrm{BN}$ and $\mathrm{J}$ areas. However, these areas exhibited high concentrations of most considered analytes accumulated in moss (Figs. 2 and 3), which may indicate earlier deposition and contamination of soil. Before the 1990s systemic transformation in Poland, the $\mathrm{BN}$ area contained a military training ground as well as small industrial facilities with now inestimable emission of pollutants, such as a porcelain factory in Tułowice.

The distribution of sites with $\mathrm{CF}>0.62$ does not indicate the considered research region is affected by remote emissions of heavy metals from large industrial centers-Górnoślaski Okręg Przemysłowy in Poland, located $150 \mathrm{~km}$ to the east and south-east, and Mostecká Basin in the Czech Republic, located $200 \mathrm{~km}$ to the west.

\section{Conclusions}

The presented results of biomonitoring studies utilizing lichens and mosses provided significant information on the level of environmental pollution, directions of pollutant transport, and bioavailability of pollutants.

The comparison of results obtained for the Praded and Glacensis Euroregions with the corresponding results from other European countries showed that the concentrations of considered analytes accumulated in mosses were of similar magnitude, with the exception of cadmium. The highest concentrations of cadmium in mosses, which were determined in Bory Niemodlińskie, exceeded by several times the maximal concentrations determined in other regions of Europe.

This work presents a new method of analyzing the biomonitoring results, which utilizes the CF defined as a ratio of a difference between the analyte concentrations in lichen and in moss, to the average of these concentrations. It was hypothetically assumed that the values $\mathrm{CF}>0.62$ indicate that the deposited bioavailable forms of heavy metals were introduced to the atmosphere with primary emissions, and not by the secondary enrichment of the atmospheric aerosol with local emissions from soil. Several quoted studies on sorption mechanisms and on the comparison of concentrations of analytes accumulated in lichens and mosses support this hypothesis. However, further support is required,

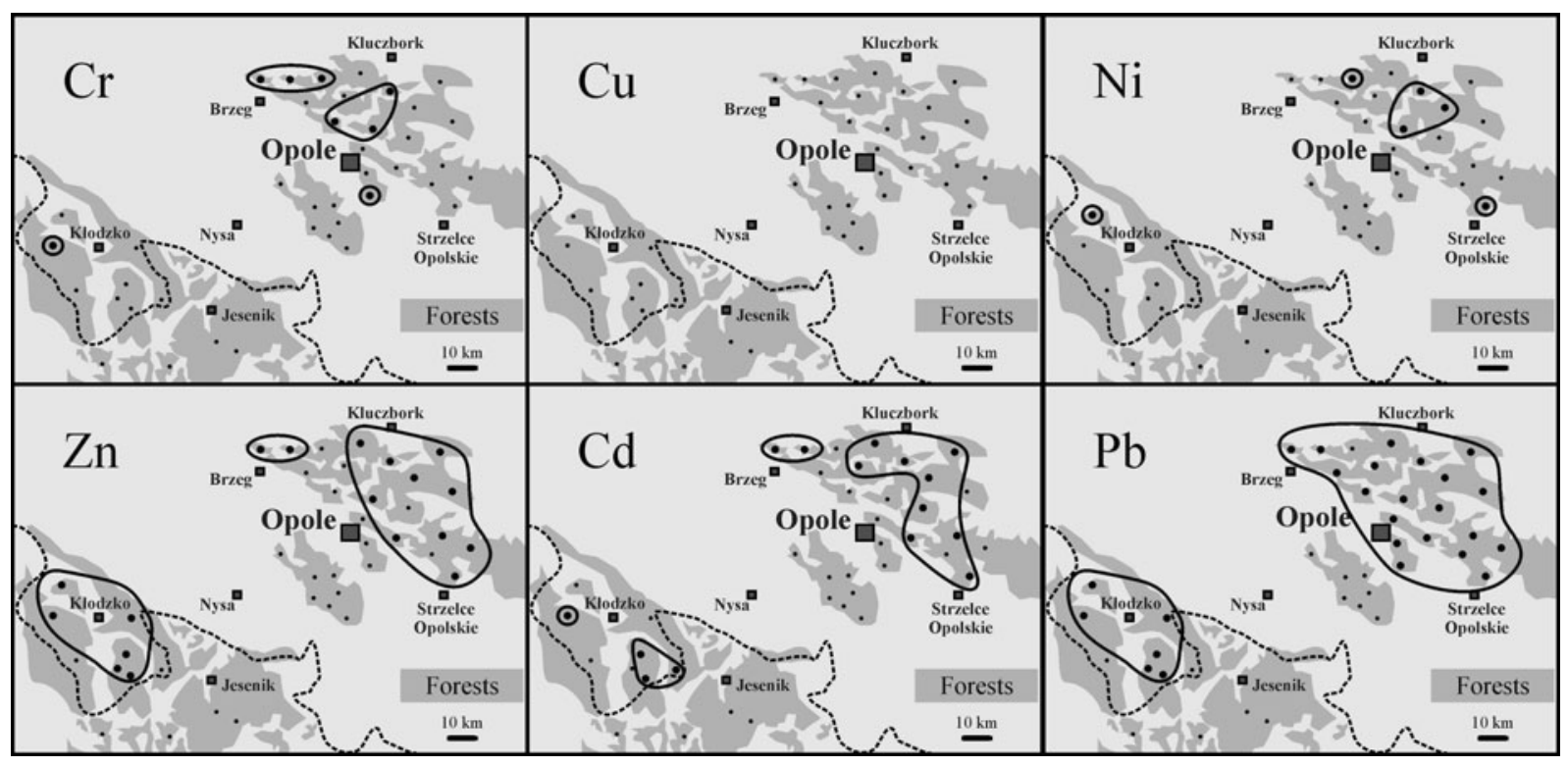

Fig. 4 Areas of the research region for which the comparison factor for specified metals exceeded $0.62(\mathrm{CF}>0.62)$ 
stemming from studies in other geographical regions. In this work, the method was used to show a significant contribution of urban emissions to the deposition of heavy metals in the area of Bory Stobrawskie and in the vicinity of Kłodzko City.

Open Access This article is distributed under the terms of the Creative Commons Attribution Noncommercial License which permits any noncommercial use, distribution, and reproduction in any medium, provided the original author(s) and source are credited.

\section{References}

Bargagli, R., Brown, D. H., \& Nelli, L. (1995). Metal biomonitoring with mosses: Procedures for correcting for soil contamination. Environmental Pollution, 89, 169-175.

Bargagli, R., Monaci, F., Borghini, F., Bravi, F., \& Agnorelli, C. (2002). Mosses and lichens as biomonitors of trace metals. A comparison study on Hypnum cupressiforme and Parmelia caperata in a former mining district in Italy. Environmental Pollution, 116, 279-287.

Bergamaschi, L., Rizzio, E., Giaveri, G., Profumo, A., Loppi, S., \& Gallorini, M. (2004). Determination of baseline element composition of lichens using samples from high elevations. Chemosphere, 55, 933-939.

Bergamaschi, L., Rizzio, E., Giaveri, G., Giordani, L., Profumo, A., \& Gallorini, M. (2005). INAA for the determination of trace elements and evaluation of their enrichment factors in lichens of high altitude areas. Journal of Radioanalytical and Nuclear Chemistry, 263(3), 721-724.

Chiarenzelli, J. R., Aspler, L. B., Dunn, C., Cousens, B., Ozarko, D. L., \& Powis, K. B. (2001). Multi-element and rare earth element composition of lichens, mosses, and vascular plants from the Central Barrenlands, Nunavut, Canada. Applied Geochemistry, 16, 245-270.

Culicov, O. A., \& Yurukova, L. (2006). Comparison of element accumulation of different moss- and lichen-bags, exposed in the city of Sofia (Bulgaria). Journal of Atmospheric Chemistry, 55, 1-12.

Daillant, O., Kirchner, G., Beltramo, J.L., Gueidan, C., Jacquiot, L., Joyeux, et al. (2003). Lichens and new possibilities of bio-indication in France. Proc. of the International Workshop-BioMAP II, 28 August-3 September 2000. (pp. 118-125).Vienna, IAEA.

Directive 2000/60/EC of the European Parliament and of the Council of 23 October 2000 establishing a framework for Community action in the field of water policy.

Ecophysiographic Development for Lower Silesia. (2005). Wojewódzkie Biuro Urbanistyczne we Wrocławiu, Wroclaw (PL).

Fraenzle, S., \& Markert, B. (2007). Metals in biomass: From the biological system of elements to reasons of fractionation and element use. Environmental Science and Pollution Research, 6, 404-413.

Freitas, M. C., Pacheco, A. M. G., Baptista, M. S., Dionísio, I., Vasconcelos, M. T. S. D., \& Cabral, J. P. (2007). Response of exposed detached lichens to atmospheric elemental deposition. Ecological Chemistry and Engineering, 14(7), 631-644.

Frontasyeva, M., Nazarov, V., Grass, F., \& Steinnes, E. (1995). Intercomparison of moss reference material by different multi-element techniques. Journal of Radioanalytical and Nuclear Chemistry, 192, 371-379.

Fuga, A., Saiki, M., Marcelli, M. P., \& Saldiva, P. H. N. (2008). Atmospheric pollutants monitoring by analysis of epiphytic lichens. Environmental Pollution, 151, 334-340.

Gałuszka, A. (2005). The chemistry of soils, rocks and plant bioindicators in three ecosystems of the Holy Cross Mountains, Poland. Environmental Monitoring and Assessment, 110, 55-70.

Harmens, H., Norris, D. A., Steinnes, E., Kubin, E., Piispanen, J., Alber, R., et al. (2010). Mosses as biomonitors of atmospheric heavy metal deposition: Spatial patterns and temporal trends in Europe. Environmental Pollution, 158, 3144-3156.

Hauck, M., Hesse, V., \& Runge, M. (2002). Correlations between the $\mathrm{Mn} / \mathrm{Ca}$ ratio in stemflow and epiphytic lichen abundance in a dieback-affected spruce forest of the Harz Mountains, Germany. Flora, 197, 361-369.

Hyvärinen, By M., \& Crittenden, P. D. (1996). Cation ratios in Cladonia portentosa as indices of precipitation acidity in the British Isles. The New Phytologist, 132, 521-532.

Jasan, R. C., Verburg, T. G., Wolterbeek, H Th, Plá, R. R., \& Pignata, M. L. (2004). On the use of the lichen Ramalina celastri (Spreng.) Krog. \& Swinsc. as an indicator of atmospheric pollution in the province of Córdoba, Argentina, considering both lichen physiological parameters and element concentrations. Journal of Radioanalytical and Nuclear Chemistry, 259, 93-97.

Kashulina, G., de Caritat, P., \& Reimann, C. (1998). Acidity ststus mobility of $\mathrm{Al}$ in podzols near $\mathrm{SO}_{2}$ emission sources on the Kola Peninsula, NW Russia. Applied Geochemistry, 13, 391-402.

Kłos, A. (2009). Porosty $w$ biomonitoringu środowiska (Lichens in environmental biomonitoring). Opole, Poland: Wyd. Uniwerstyetu Opolskiego.

Kłos, A., Rajfur, M., Wacławek, M., \& Wacławek, W. (2005). Ion equilibrium in lichen surrounding. Bioelectrochemistry, 66, 95-103.

Kłos, A., Rajfur, M., Wacławek, M., \& Wacławek, W. (2007). Heavy metal sorption in the lichen cationactive layer. Bioelectrochemistry, 71, 60-65.

Kłos, A., Rajfur, M., Wacławek, M., Wacławek, W., Wünschmann, S., \& Markert, B. (2010). Quantitative relations between different concentrations of micro- and macroelements in mosses and lichens: the region of Opole (Poland) as an environmental interface in between Eastern and Western Europe. International Journal of Environmental Heath, 4(2/3), 98-119.

Kosior, G., Samecka-Cymerman, A., Kolon, K., \& Kempers, A. J. (2010). Bioindication capacity of metal pollution of native and transplanted Pleurozium schreberi under various levels of pollution. Chemosphere, 81, 321-326.

Loppi, S., \& Bonini, I. (2000). Lichens and mosses as biomonitors of trace elements in areas with thermal springs and fumarole activity (Mt. Amiata, central Italy). Chemosphere, 41, 1333-1336. 
Loppi, S., Giomarelli, B., \& Bargagli, R. (1999). Lichens and mosses as biomonitors of trace elements in a geothermal area (Mt. Amiata, central Italy). Cryptogamie. Mycologie, 20(2), 119-126.

Lucaciu, A., Timofte, L., Culicov, O., Frontasyeva, M. V., Oprea, C., Cucu-Man, S., et al. (2004). Atmospheric Deposition of Trace Elements in Romania Studied by the Moss Biomonitoring Technique. Journal of Atmospheric Chemistry, 49, 533-548.

Markert, B. (1996). Instrumental element and multi-element analysis of plant samples: Methods and applications. Chichester, New York: John Wiley \& Sons.

Markert, B. (2007). Definitions and principles for bioindication and biomonitoring of trace metals in the environment. Journal of Trace Elements in Medicine and Biology, 21 (S1), 77-82.

Markert, B., Breure, A., \& Zechmeister, H. (2003). Bioindicators \& biomonitors: Principles. Amsterdam, Elsevier: Concepts and Applications.

Markert, B., Wuenschmann, S., Fraenzle, S., Wappelhorst, O., Weckert, V., Breulmann, G., et al. (2008). On the road from environmental biomonitoring to human health aspects: Monitoring atmospheric heavy metal deposition by epiphytic/epigeic plants: Present status and future needs. International Journal of Environment and Pollution, 32, 486-498.

McGill, R., Tukey, J. W., \& Larsen, W. A. (1978). Variations of box plots. American Statistical Association, 32(1), 12-16.

Olendrzyński K., Dębski B., Kargulewicz I., Skośkiewicz J., Fudała J., Haławiczka S., et al. (2003). Inwentaryzacja emisji zanieczyszczeń powietrza za rok 2001 na potrzeby statystyki krajowej i zobowiązań międzynarodowych w ramach Konwencji w sprawie transgranicznego zanieczyszczenia powietrza na dalekie odległości. Instytut Ochrony Środowiska (Institute of Environmental Protection), Krajowe Centrum Inwentaryzacji Emisji (National Emission Centre), Warsaw.

Reimann, C., Halleraker, J. H., Kashulina, G., \& Bogatyrev, I. (1999). Comparison of plant and precipitation chemistry in catchments with different levels of pollution on the Kola Peninsula, Russia. The Science of the Total Environment, 243(244), 169-191.
Reis, M.A., Freitas, M.C., De Goeij, J., \& Wolterbeek, H.Th. (2003). Surface-layer model of lichen uptake, modelling $\mathrm{Na}$ response. Proc. of the International WorkshopBioMAP II, 28 August-3 September 2000. (pp. 152159) Vienna, IAEA.

Riga-Karandinos, A. N., \& Karandinos, M. G. (1998). Assessment of air pollution from a lignite power plant in the plain of Megalopolis (Grecce) using as biomonitors three species of lichens; impacts on some biochemical parameters of lichens. The Science of the Total Environment, 215, 167-183.

Smodiš, B., Pignata, M. L., Saiki, M., Cortés, E., Bangfa, N., Markert, B., et al. (2004). Validation and application of plants as biomonitors of trace element atmospheric pollution-A co-ordinated effort in 14 countries. Journal of Atmospheric Chemistry, 49, 3-13.

Sorbo, S., Aprile, G., Strumia, S., Castaldo Cobianchi, R., Leone, A., \& Basile, A. (2008). Trace element accumulation in Pseudevernia furfuracea (L.). Zopf exposed in Italy's so called Triangle of Death. Science of the Total Environment, 407, 647-654.

Suchara, I., Maňkovská, B., Sucharová, J., Florek, M., Godzik, B., Rabnecz, G., et al. (2007). Mapping of main sources of pollutants and their transport in the Visegrad space. Part II: Fifty three elements. Project 11007-2006-IVF. KLEMO spol. s r.o., (Ltd.), Zvolen, Slovak Republic.

Szarek-Łukaszewska, M., Grodzińska, K., \& Braniewski, S. (2002). Heavy metal concentration in the moss Pleurozium schreberi in the Niepołomice Forest, Poland: Changes during 20 years. Environmental Monitoring and Assessment, 79(3), 231-237.

Szczepaniak, K., Astel, A., Simeonov, V., Tsakovski, S., Biziuk, M., Bode, P., et al. (2007). Comparison of dry and living Sphagnum palustre moss samples in determining their biocumulative capability as biomonitoring tools. Journal of Environmental Science and Health, Part A: Toxic/Hazardous Substances and Environmental Engineering, 42(8), $1101-1115$.

Wolterbeek, B. (2003). Biomonitoring of trace element air pollution: principles, possibilities and perspectives. Proc. of the International Workshop-BioMAP II, 28 August-3 September 2000. (pp. 87-104) Vienna, IAEA. 